FAMILY SUPPORT PADA PENDERITA DIABETES MELLITUS TIPE 2 DI PUSKESMAS BANGETAYU SEMARANG, ANALISIS RASCH MODEL

\author{
Iskim Luthfa ${ }^{1}$
}

Fakultas IImu Keperawatan, Universitas Islam Sultan Agung Semarang

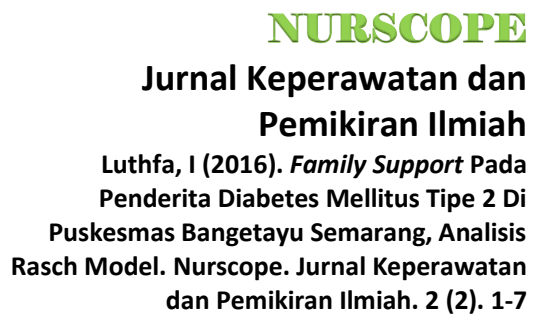

NURSCOPI

eperawatan dan

Luthfa, I (2016). Family Support Pada Penderita Diabetes Mellitus Tipe 2 Di Puskesmas Bangetayu Semarang, Analisis dan Pemikiran IImiah. 2 (2). 1-7

\begin{abstract}
ABSTRAK
Diabetes Mellitus merupakan penyakit kronik yang akan diderita seumur hidup. Penderita DM tipe-2 dianjurkan melakukan perawatan diri secara rutin untuk mencegah terjadinya komplikasi yang lebih parah. Perawatan diri yang dilakukan secara rutin akan menimbulkan perasaan bosan dan jenuh sehingga menyebabkan penderita DM tipe 2 tidak disiplin melakukan perawatan diri. Dukungan keluarga sangat membantu penderita DM tipe 2 untuk tetap disiplin melakukan perawatan diri. Namun tidak semua keluarga mampu memberikan dukungan secara efektif. Jenis penelitian ini adalah deskriptif analitis, dengan jumlah sampel sebanyak 56 responden. Analisis data menggunakan Model RASCH (Rasch Measurement Model). Instrument untuk mengetahui family support menggunakan kuesionair Hensarling Diabetes Family Support Scale (HDFSS). Hasil penelitian ini menunjukkan family support kepada penderita DM tipe 2 sebagian besar rendah $(67,9 \%)$, dengan bentuk dukungan yang paling mudah diberikan yaitu berkaitan dengan support emosional $(-4,05)$ dan dukungan yang paling sulit diberikan yaitu berkaitan dengan support informasi $(1,71)$. Hasil penelitian ini memberikan kontribusi penanganan penyakit DM memerlukan dukungan keluarga (family support), sehingga perlu disusun strategi intervensi untuk meningkatkan family support.
\end{abstract}

Kata kunci : Family Support, Diabetes Mellitus tipe-2, RASCH MODEL.

\title{
FAMILY SUPPORT IN PATIENTS OF TYPE 2 DIABETES MELLITUS BANGETAYU HEALTH CENTER IN SEMARANG, RASCH MODEL ANALYSIS
}

\begin{abstract}
Diabetes mellitus is a chronic disease that will be suffered lifetime. Patients with type 2 DM are encouraged to do self-care regularly to prevent severe complications. Self-care which is performed routinely would induce a feeling of bored and tired, thereby causing type 2 diabetes patients become undisciplined doing self-care. Family support helps people with type 2 diabetes to stay disciplined perform self-care. But not all families are able to provide effective support. This research is descriptive analytic, with total sample of 56 respondents. Analysis of data used Rasch Model (Rasch Measurement Model). Instrument to determine family support used Hensarling Diabetes Family Support Scale (HDFSS). The results of this study indicated that family support to word patients with type 2 diabetes were mostly low (67.9\%), the easiest form of support given was related to emotional support $(-4,05)$ and the most difficult support was support related information $(1.71)$. The results of this study contributes to word diabetes disease management needs family support (family support), thus it is necessary to develop intervention strategies to improve family support.
\end{abstract}

Keywords: Family Support, Diabetes Mellitus Type 2, Rasch MODEL.

Corresponding Author :

Iskim Luthfa ${ }^{1}$, Fakultas IImu Keperawatan Universitas Islam Sultan Agung, Jalan Raya Kaligawe Km 4, Semarang, Jawa Tengah, Indonesia, Kode pos 50112; e-mail iskim.ners@gmail.com 


\section{PENDAHULUAN}

Prevalensi dan insidensi jumlah penderita diabetes mellitus (DM) di dunia semakin mengkhawatirkan. Menurut World Health Organization (WHO) jumlah penderita DM di dunia pada tahun 2000 sudah mencapai 171 juta orang, dan diprediksi pada tahun 2030 jumlahnya akan meningkat sebesar $114 \%$ atau mencapai 366 juta orang. Kenaikan jumlah penderita DM ini terjadi di Negara maju dan $80 \%$ nya di Negara berkembang khususnya yang paling cepat pertumbuhan ekonominya (International Diabetes Federation, 2011).

WHO melakukan analisis, jumlah penderita DM di Indonesia pada tahun 2000 mencapai 8,4 juta, dan dikatakan bahwa Indonesia menempati urutan keempat terbanyak di dunia setelah Negara Amerika Serikat, China dan India. Diperkirakan pada tahun 2030 Indonesia masih tetap menempati urutan keempat, dengan prediksi akan terjadi peningkatan jumlah penderita DM mencapai 21,3 juta (Wild, Roglic, Green, Sicree \& King, 2004).

Setiap tahun di Indonesia terjadi peningkatan penderita DM tidak hanya dari segi prevalensinya namun juga morbiditasnya, dan yang mengejutkan adalah usia penderitanya. Hasil Riskesdas yang dilakukan pada tahun 2007 menunjukkan bahwa angka mortalitas akibat DM masih cukup tinggi dengan proporsi kematian sebanyak 5,7\%. Penderita DM tipe-2 setiap tahun mengalami pemudaan usia, jika DM tipe-1 terjadi pada anak-anak maka hal ini tidak mengherankan, mengingat penyebab DM tipe-1 karena faktor keturunan jadi wajar sudah diderita sejak kecil. Tetapi DM tipe-2 sudah diderita pada seseorang yang usianya jauh lebih muda, dimana rentang usia 15-24 tahun jumlah penderita DM tipe-2 sebanyak 0,6 \% dari total penderita DM, dan kematian akibat penyakit DM rentang usia 15-44 tahun sebanyak 6,6\%.

Diabetes mellitus (DM) merupakan penyakit akibat gangguan metabolik yang ditandai dengan terjadinya peningkatan kadar glukosa di dalam darah (hiperglikemia). Penyakit ini terjadi dalam jangka waktu lama, akibat kelainan sekresi insulin, kerja insulin, maupun keduanya (ADA, 2013). Penyakit ini akan diderita seumur hidup, sehingga diharapkan penderita DM tipe-2 mampu melakukan perawatan diri (self care) dengan membentuk perilaku yang relevan terhadap penyakitnya untuk menghindari ketidakstabilan kadar glukosa darah yang dapat menimbulkan komplikasi yang lebih parah (Kusniyah, Nursiswati \& Urip, 2011; Cox \& Gonder, 2008). Perilaku self care bagi penderita DM meliputi; perilaku aktivitas fisik (olahraga), perilaku pengaturan diet, perilaku dalam mengontrol kadar glukosa darah, perilaku pengobatan, serta perilaku pencegahan komplikasi (American Association of Diabetic Educator, 2003).

Mematuhi serangkaian tindakan self care secara rutin yang akan berlangsung seumur hidup pada dasarnya merupakan tantangan yang besar dan bukan hal yang mudah untuk dilakukan. Perasaan 
jenuh maupun bosan dapat muncul setiap saat yang menyebabkan penderita DM tidak lagi disiplin melakukan tindakan self care. Sehingga, dukungan keluarga (family support) sangat dibutuhkan untuk membantu agar penderita DM tipe-2 memiliki keyakinan dan kemampuan untuk tetap melakukan tindakan self care (Tamara, Bayhakki \& Nauli, 2014)

Family support dapat dilakukan dengan cara mengoptimalkan fungsi keluarga dalam membantu penderita DM tipe-2 supaya mampu beradaptasi dan mematuhi tindakan self care melalui empat dimensi antara lain, dimensi empathetic (emosional), dimensi encouragement (penghargaan), dimensi facilitative (instrumental), dan dimensi participative (pastisipasi) (Hensarling, 2009).

\section{METODE}

Penelitian ini merupakan jenis penelitian deskriptif analitis, dengan jumlah sampel sebanyak 56 responden. Analisis data menggunakan Model RASCH (Rasch Measurement Model). Model RASCH mampu mengubah data ordinal menjadi interval dengan cara mentransformasikan logaritma pada fungsi rasio odd. Sehingga didapatkan data dalam bentuk equal dan interval, yang ditampilkan dalam bentuk nilai logit (logaritma odds digit) measure. Nilai logit measure inilah yang kemudian peneliti gunakan untuk analisis. Instrument untuk mengetahui family support menggunakan kuesionair Hensarling Diabetes Family Support Scale (HDFSS) yang dikembangkan oleh Hensarling pada tahun 2009.

\section{HASIL}

1. Karakteristik responden penderita DM tipe-2

Tabel 1.1 Distribusi frekuensi karakteristik responden penderita DM tipe-2 di Puskesmas Bangetayu Semarang.

\begin{tabular}{|c|c|c|c|}
\hline \multirow[t]{2}{*}{ No } & \multirow[t]{2}{*}{ Variabel } & \multicolumn{2}{|c|}{$n=56$} \\
\hline & & $\mathrm{F}$ & $\%$ \\
\hline \multirow[t]{5}{*}{1.} & Usia responden & & \\
\hline & a. $30-40$ & - & 0 \\
\hline & b. $41-50$ & 12 & 21,4 \\
\hline & c. 51-60 & 39 & 69,6 \\
\hline & d. $61-70$ & 5 & 9 \\
\hline \multirow[t]{3}{*}{2.} & Jenis kelamin & & \\
\hline & a. Laki-laki & 21 & 37,5 \\
\hline & b. Perempuan & 35 & 62,5 \\
\hline
\end{tabular}

3. Pendidikan 


\begin{tabular}{llcc}
\hline a. & SD & 24 & 42,9 \\
\hline b. & SMP & 8 & 14,3 \\
\hline c. & SMA & 20 & 35,7 \\
\hline d. & PT & 4 & 7,1
\end{tabular}

4. Lama sakit DM

\begin{tabular}{llcc}
\hline a. & $<1$ tahun & 30 & 53,6 \\
\hline b. & $1-5$ tahun & 22 & 39,2 \\
\hline c. & $6-10$ tahun & 2 & 3,6 \\
\hline d. $\quad>10$ tahun & 2 & 3,6
\end{tabular}

Tabel di atas menunjukkan responden sebagian besar berusia 51-60 tahun sebanyak 39 orang $(69,6 \%)$. Responden sebagian besar berjenis kelamin perempuan sebanyak 35 orang (62,5\%). Responden sebagian besar memiliki tingkat pendidikan SD sebanyak 24 orang (42,9\%). Lama responden menderita sakit DM tipe-2 sebagian besar lamanya < 1 tahun sebanyak 30 orang $(53,6 \%)$.

2. Karakteristik Keluarga (caregiver)

Tabel 2.1. Distribusi frekuensi karakteristik keluarga (caregiver) penderita DM tipe-2 di Puskesmas Bangetayu Semarang.

\begin{tabular}{|c|c|c|c|}
\hline \multirow[t]{2}{*}{ No. } & \multirow[t]{2}{*}{ Variabel } & \multicolumn{2}{|c|}{$n=56$} \\
\hline & & $\mathrm{F}$ & $\%$ \\
\hline \multirow[t]{3}{*}{1.} & Tipe Keluarga & & \\
\hline & a. Nuclear Family & 48 & 85,7 \\
\hline & b. Extended Family & 8 & 14,3 \\
\hline \multirow[t]{4}{*}{2.} & Caregiver & & \\
\hline & a. Suami & 24 & 42,9 \\
\hline & b. Istri & 21 & 37,5 \\
\hline & c. Anak & 11 & 19,6 \\
\hline \multirow[t]{4}{*}{3.} & Pendidikan caregiver & & \\
\hline & a. SD & 17 & 30,4 \\
\hline & b. SMP & 10 & 17,8 \\
\hline & c. SMA & 27 & 48,2 \\
\hline
\end{tabular}



d. PT
2
3,6

4. Ekonomi

\begin{tabular}{ccc}
\hline a. $\quad$ < UMR & 30 & 53,6 \\
\hline b. $\quad>$ UMR & 26 & 46,4 \\
\hline
\end{tabular}

Tabel di atas menunjukkan sebagian besar tipe keluarga responden adalah nuclear family (keluarga inti) sebanyak 48 orang (85,7\%). Anggota keluarga yang merawat (caregiver utama) sebagian besar adalah suami sebanyak 24 orang (42,9\%). Pendidikan caregiver sebagian besar tingkat SMA sebanyak 27 orang (48,2\%). Status ekonomi berdasarkan upah minimum regional (UMR) per bulan sebagian besar di bawah UMR, sebanyak 30 orang $(53,6 \%)$.

\section{Family Support}

Tabel 3.1. Distribusi frekuansi Family support pada penderita DM tipe 2 di Puskesmas Bangetayu Semarang.

\begin{tabular}{lcccc}
\hline No. & Variabel & \multicolumn{2}{c}{$\mathrm{n}=56$} \\
\cline { 3 - 4 } & & & $\mathrm{F}$ & $\%$ \\
\hline 1. & a. & Family support tinggi & 18 & 32,1 \\
\cline { 2 - 4 } & b. Family support rendah & 38 & 67,9 \\
\hline
\end{tabular}

Tabel di atas menunjukkan sebagian besar keluarga memberikan dukungan (family support) kepada anggotanya yang sakit DM rendah, sebanyak 38 orang (67,9\%). 
Tabel 3.2. Logit item measure Family Support pada penderita DM Tipe 2 di Puskesmas Bangetayu Semarang.

Item STATISTICS: ITEM MEASURE (family support)

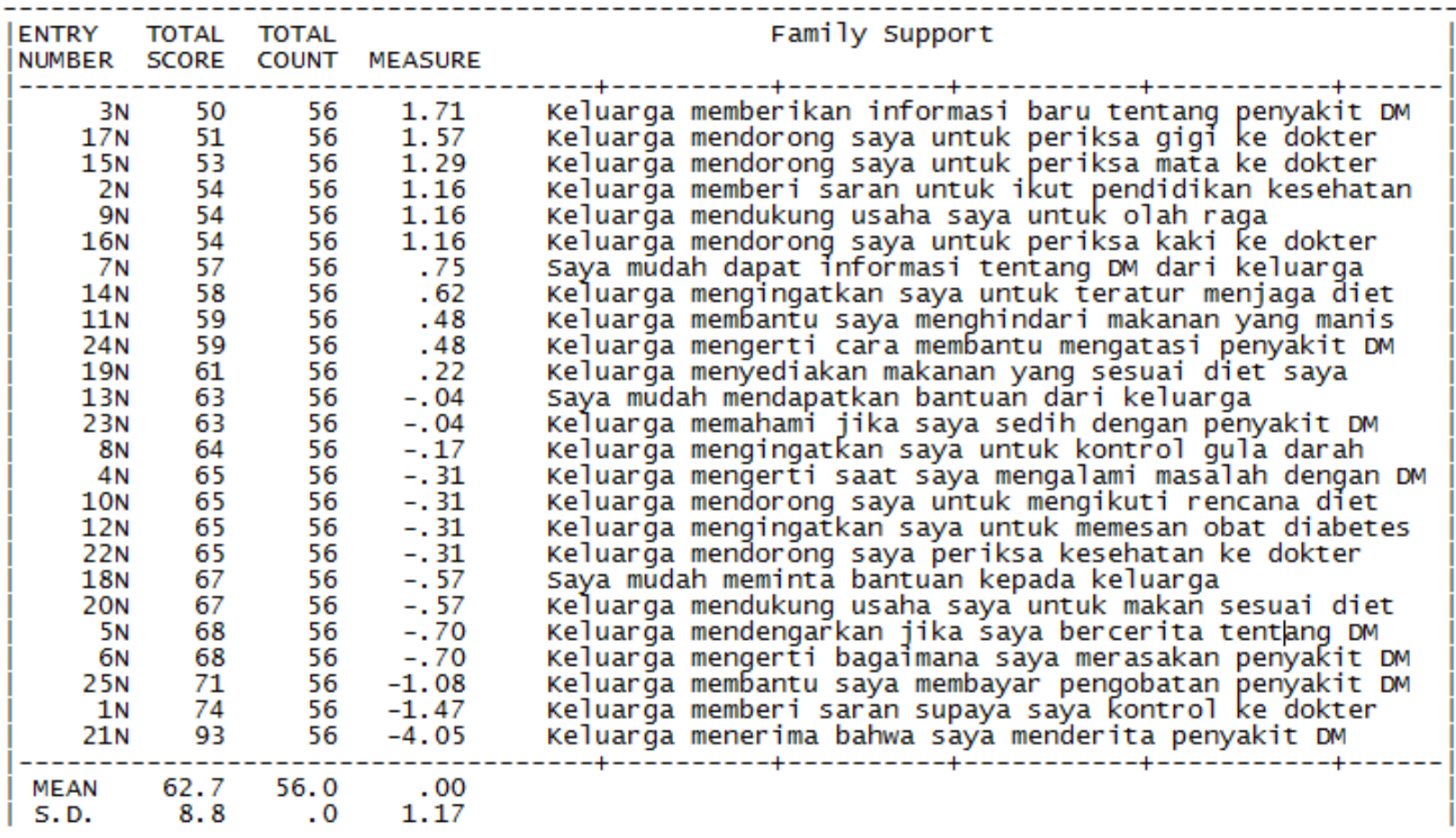

Tabel analisis RASCH MODEL di atas menunjukkan nilai logit item measure yang tertinggi pada item N3 dengan nilai 1,71 itu artinya keluarga sulit memberikan dukungan pada item pertanyaan nomor 3 yaitu berkaitan dengan support informasi. Nilai logit item measure yang terendah pada item N21 dengan nilai $-4,05$, itu artinya dukungan yang paling mudah diberikan oleh keluarga adalah pada item pertanyaan nomor 21 yaitu berkaitan dengan support emosional (menerima kondisi penyakit DM).

\section{PEMBAHASAN}

Diabetes Mellitus merupakan penyakit metabolik yang bersifat kronik yang artinya meskipun dapat dikontrol namun penyakit ini akan berlangsung seumur hidup. Jumlah penderita DM tipe-2 setiap tahun mengalami peningkatan, berdasarkan tabel 1.1 perempuan lebih banyak menderita DM tipe 2 . Perempuan lebih cenderung mengalami penyakit DM tipe-2 dibandingkan pada laki-laki, faktor penyebabnya antara lain karena obesitas. Berdasarkan hasil Riskesdas (2013) data perempuan yang mengalami obesitas lebih tinggi dibandingkan laki-laki. Jumlah perempuan yang mengalami obesitas pada tahun 2007 mencapai 14,8\%, pada tahun 2013 jumlahnya meningkat menjadi 32,9\%. Sedangkan jumlah laki-laki yang mengalami obesitas pada tahun 2007 mencapai 13,9\%, pada tahun 
2013 jumlahnya meningkat mencapai 19,7\%. Faktor lainnya karena kondisi tertentu yang hanya terjadi pada wanita yaitu kehamilan (gestasional), wanita yang memiliki riwayat persalinan dengan bayi besar (lebih dari $4 \mathrm{~kg}$ ) memiliki resiko terkena DM tujuh kali lipat dibandingkan dengan wanita yang hamil normal.

Faktor lainnya penyebab DM tipe-2 adalah faktor usia, berdasarkan tabel 1.1 diketahui penderita DM tipe-2 sebagian besar berusia 51-60 tahun. Usia menjadi faktor penting resiko terjadinya DM, usia dikaitkan dengan terjadinya penurunan fungsi sel pankreas dan berkurangnya sekresi hormon insulin sehingga semakin tua usia seseorang maka resiko terjadinya DM semakin tinggi.

Diabetes mellitus tidak akan terdeteksi bila tidak dicari penyebabnya, hampir $70 \%$ dari penderita DM tipe-2 tidak mengetahui kalau dirinya sedang mengalami DM, sebagian besar ketika terdeteksi sudah mengalami komplikasi hingga akhirnya meninggal dunia. Berdasarkan tabel 1.1 diketahui lama responden menderita sakit DM tipe-2 sebagian besar lamanya $<1$ tahun. Deteksi dini dengan cara pemeriksaan kadar gula darah sangat dianjurkan sebagai bagian dari level of prevention. Selain itu upaya pemeliharaan pola hidup yang sehat dan perawatan diri secara efektif dinilai mampu mencegah komplikasi dan kematian.

Berdasarkan tabel 1.1 diketahui pendidikan responden sebagian besar tingkat SD. Pendidikan memiliki keterkaitan dengan perilaku perawatan diri, hal ini sesuai dengan penelitian yang dilakukan oleh Ismonah (2009) yang menyatakan bahwa terdapat hubungan antara pendidikan dengan self care management DM. Pendidikan adalah faktor penting seseorang mampu memahami penyakit, mampu melakukan perawatan diri, melakukan pengelolaan DM tipe-2 untuk mengontrol gula darah sehingga penderita DM tipe-2 tetap memiliki kualitas hidup optimal (Yusra, 2011).

Keberhasilan penderita DM melakukan perawatan diri tidak terlepas dari support seluruh anggota keluarganya. Dukungan keluarga sangat dipengaruhi oleh karakteristik dari responden penderita DM tipe-2 itu sendiri dan karakteristik keluarga yang tinggal bersama. Berdasarkan tabel 2.1 diketahui bahwa sebagian besar tipe keluarga responden adalah nuclear family (keluarga inti). Menurut Feiring \& Lewis (1984 dalam friedman, 2010) secara kualitatif penderita DM yang berasal dari tipe nuclear family akan menerima support lebih banyak dibandingkan penderita DM yang berasal dari extended family yang tinggal bersama. Tipe keluarga inti memiliki kecenderungan memiliki perhatian yang lebih besar kepada anggota keluarganya yang sedang sakit, hal ini akan menunjang keberhasilan program pemeliharaan dan perawatan diri penderita DM tipe-2.

Karakteristik lain dari keluarga adalah siapa pemberi asuhan keperawatan utama (primary caregiver) kepada anggota keluarga yang menderita penyakit DM tipe-2 di rumah. Berdasarkan tabel 2.1 diketahui anggota keluarga yang merawat (primary caregiver) sebagian besar adalah suami. Peran 
caregiver bervariasi sesuai dengan status dan keterkaitannya dengan penerima asuhan, caregiver akan mengalami perubahan peran secara bermakna ketika yang menjadi caregiver adalah orang tua, suami atau istri, anak, saudara kandung, ataupun teman (Friedman, 2010).

Karakteristik selanjutnya adalah tingkat pendidikan caregiver dan status ekonomi keluarga. Berdasarkan tabel 2.1 diketahui pendidikan caregiver sebagian besar tingkat SMA dan status ekonomi berdasarkan upah minimum regional (UMR) per bulan sebagian besar di bawah UMR.

Pendidikan dikaitkan dengan kemampuan menerima informasi, semakin tinggi pendidikan family support provider maka akan semakin baik dalam menerima informasi dan akan meningkatkan support terhadap penderita DM. Demikian pula dengan status ekonomi, DM merupakan penyakit kronik sehingga memerlukan perawatan dalam jangka panjang yang secara rutin penderitanya harus kontrol ke pelayanan kesehatan dan membutuhkan bantuan biaya pengobatan.

Penelitian terdahulu telah membuktikan bahwa Family support menjadi faktor penting dalam kepatuhan managemen penyakit kronik, dan juga sebagai indikator dampak positif terhadap self care pasien diabetes (Neff dalam Hensarling, 2009). Namun kenyataannya tidak semua keluarga memiliki support yang efektif dalam menghadapi masalah anggota keluarga dengan penyakit kronis. Berdasarkan pada tabel 3.1 diketahui sebagian besar keluarga memiliki family support rendah.

Dukungan keluarga atau family support adalah suatu proses pemberian bantuan yang diberikan keluarga kepada anggota keluarga lainnya yang memiliki masalah kesehatan guna memelihara dan meningkatkan derajat kesehatannya. Coffman (2008) menyatakan bahwa keluarga merupakan sumber pemberi dukungan yang paling utama. Menurut Hensarling (2009) keluarga dalam memberikan dukungannya (support) terhadap penderita DM tipe-2 memiliki empat dimensi support yaitu support emosional / empati, support penghargaan, support instrumental dan support informasi. Support emosional dilakukan oleh keluarga dengan cara menerima dan memahami kondisi penyakit DM bahwa penyakit ini akan diderita seumur hidup oleh anggota keluarganya dan memerlukan perawatan yang panjang. Support penghargaan dilakukan oleh keluarga dengan cara memberikan umpan balik berupa respon, bimbingan maupun perhatian, bahkan pemberian pujian. Support instrumental dilakukan oleh keluarga dengan cara menyediakan waktu luang, membantu biaya pengobatan, membantu pergi ke pelayanan kesehatan, dan membantu menyediakan diit yang tepat. Sedangkan support informasi dilakukan oleh keluarga dengan cara memberikan masukan maupun saran yang membangun, memberikan arahan maupun nasehat, dan informasi yang penting lainnya untuk meningkatkan status kesehatan keluarga yang sakit.

Berdasarkan tabel 3.2 diketahui bentuk famly support yang diberikan oleh keluarga kepada responden menunjukkan bahwa, penderita DM mudah mendapatkan support dalam hal penerimaan 
kondisi penyakit DM yang dialaminya. Penerimaan keluarga terhadap kondisi apapun yang dialami oleh anggota keluarganya merupakan support emosional yang paling penting (Corneil, dalam Hasan 2013), termasuk ke dalam fungsi afektif keluarga (Friedman, 2010). Pemberian support emosional akan mendorong penderita DM tipe-2 untuk dapat mengendalikan emosi dan waspada terhadap komplikasi yang akan muncul dikemudian hari, serta mampu mengurangi rasa rendah diri, rasa putus asa dan keterbatasan akibat dari penyakit fisik yang dialami (Nugroho, 2010).

Penerimaan keluarga terhadap kondisi penyakit DM yang dialami oleh anggota keluarganya, akan mendorong keluarga untuk selanjutnya memberikan bantuan biaya pengobatan supaya penderita DM tipe-2 melakukan pemeriksaan kesehatan ke dokter. Support instrumental berupa bantuan pembiayaan kesehatan menjadi sangat penting mengingat penyakit DM akan diderita seumur hidup sehingga memerlukan pemeriksaan kesehatan secara rutin.

Berdasarkan tabel 3.2 menunjukkan bahwa penderita DM sulit mendapatkan support dari keluarga dalam hal pemberian informasi baru tentang penyakit DM. Menurut Dikkers, Dunning dan Savage (2013) Support informasi menjadi hal yang sulit diterima oleh penderita DM tipe-2 hal ini dikarenakan keluarga tidak memiliki informasi yang cukup untuk memungkinkan mereka membantu anggota keluarga mengelola diabetes. Informasi yang seharusnya dimiliki oleh keluarga mencakup bagaimana melakukan tugas-tugas perawatan diabetes, apa saja fokus perawatan yang dibutuhkan, bagaimana cara manajemen glukosa darah, EOL (end of life), dan pengambilan keputusan yang melibatkan penderita dan keluarga.

Informasi lainnya yang perlu diketahui oleh keluarga adalah apa saja komplikasi yang ditiumbulkan dari penyakit DM, hal ini diperlukan supaya keluarga ikut mendukung pencegahan komplikasi. Salah satu komplikasi dari penyakit DM yang tidak banyak diketahui adalah terjadinya periodontitis, kondisi ini menyebabkan terbentuknya kantung antara gigi dan gusi yang lama-kelamaan akan memicu berkembangnya banyak kuman, sehingga menyebabkan gusi sering berdarah dan gigi goyah, serta mudah lepas. Support keluarga dalam memberikan informasi terbaru tentang penyakit DM dan pemeriksaan kesehatan gigi seharusnya menjadi penting untuk diberikan supaya mencegah terjadinya komplikasi yang lebih parah. Pada dasarnya ke-empat dimensi support di atas hendaknya diberikan secara keseluruhan oleh keluarga, karena saling berhubungan dan saling menunjang terhadap keberhasilan perawatan kesehatan anggota keluarga yang sakit DM.

\section{SIMPULAN DAN IMPLIKASI PENELITIAN}

Karakteristik responden sebagian besar perempuan berusia 51-60 tahun, pendidikan SD dan sudah menderita DM tipe 2 kurang dari satu tahun. Karakteristik keluarga (caregiver) sebagian besar tipe 
keluarga nuclear family, caregiver utama adalah suami, dengan pendidikan SMA, dan memiliki status ekonomi dengan penghasilan di bawah UMR. Family support kepada penderita DM tipe 2 sebagian besar rendah, dengan bentuk dukungan yang paling mudah diberikan yaitu berkaitan dengan support emosional (menerima kondisi penyakit DM) dan dukungan yang paling sulit diberikan yaitu berkaitan dengan support informasi.

Hasil penelitian ini sebagai bukti ilmiah sehingga dapat memberikan kontribusi terhadap peningkatan khasanah keilmuan terutama keperawatan keluarga. Secara teoritis penambahan materi dukungan keluarga yang ditinjau dari empat dimensi bagi penderita DM tipe-2 bisa diberikan di institusi pendidikan sebagai landasan kemampuan perawat yang akan melakukan asuhan keperawatan keluarga dan hasil penelitian ini dapat dikembangkan melalui penelitian lanjutan.

\section{DAFTAR PUSTAKA}

ADA. (2013). Diagnosis and classification of diabetes mellitus. doi: 10.2337/dc10-S062 Diabetes Care January 2010 vol. 33 no. Supplement 1 S62-S69.

American Association of Diabetic Educator. (2003). Standards for outcomes measurement of diabetes self-management education. The Diabetes Educator Volume 29, Number 5.

Cox \& Gonder. (2008). Major developments in behavioral diabetes research. J Consult Clin Psychol 1992, 60(4):628-638.

Dikkers, M.F., Dunning, T., and Savage, S. (2013). Information needs of family carers of people with diabetes at the End of Life: A literature review. Journal of paliatif medicine, volume 16, number 12. DOI: 10.1089/jpm.2013.0265

Friedman. (2010). Keperawatan Keluarga. Jakarta: Penerbit Buku Kedokteran.

Hasan. (2013). Hubungan antara penerimaan diri dan dukungan emosi dengan optimisme pada penderita diabetes mellitus anggota aktif PERSADIA (Persatuan diabetes Indonesia) Cabang Surakarta, www.candrajiwa.psikologi. fk.uns.ac.id/ index.php/ candrajiwa/article/.../52/44, diunduh pada tanggal 8 Februari 2015.

Hensarling. (2009). Development and psychometric testing of HEnsarling's diabetes family support scale, a dissertation. Degree of Doctor of Philosophi in the Graduate School of Texa's Women"s University. .

International Diabetes Federation. (2011). Diabetes atlas : impact on the individual, (online), (http://da3.diabetesatlas.org/index68fc.html, diakses 9 Desember 2014). 
Kusniyah, Nursiswati \& Urip. (2011). Hubungan tingkat self care dengan tingkat HBA1C pada klien diabetes mellitus tipe-2 di Poliklinik Endokrin RSUP DR. Hasan Sadikin Bandung. Repository. Unpad.ac.id.

Nugroho. (2010). Keperawatan gerontik. Jakarta : Gramedia.

Riskesdas. (2013). Badan penelitian dan pengembangan kesehatan kementerian kesehatan RI. www.litbang.depkes.go.id

Sumintono, B. \& Widhiarso, W. (2014). Aplikasi model RAsch untuk penelitian ilmu-ilmu sosial. Cimahi :Trim Komunikata Publishing House.

Tamara, Bayhakki \& Nauli. (2014). Hubungan antara dukungan keluarga dengan kualitas hidup pasien diabetes mellitus tipe-2 di RSUD Arifin Achmad Provinsi Riau. JOMPSIK Vol.1 No.12 Oktober 2014.

Wild, Roglic, Green, Sicree \& King. (2004). Global prevalence of diabetes: estimates for the year 2000 and projections for 2030. Diabetes Care, 27(5), 1047-1053.

Yusra. (2011). Hubungan antara dukungan keluarga dengan kualitas hidup pasien diabetes mellitus tipe-2 di Poliklinik Peyakit Dalam RSUP Fatmawati Jakarta. Repository.UI.ac. 
ISSN 2476 - 8987 